\title{
Detection of Mycobacterium leprae infection in wild nine-banded armadillos (Dasypus novemcinctus) using the rapid ML Flow test
}

\section{Detecção de infecção pelo Mycobacterium leprae em tatus selvagens da espécie Dasypus novemcinctus utilizando o teste rápido ML Flow}

\author{
Patrícia Duarte Deps $^{1}$, João Marcelo Azevedo de Paula Antunes ${ }^{1}$ \\ and Jane Tomimori-Yamashita ${ }^{2}$
}

\begin{abstract}
Mycobaterium leprae infection was investigated in armadillos from the State of Espirito Santo, Brazil. The ML Flow test was performed on 37 nine-banded armadillos and positive results were found in 11 (29.7\%). The ML Flow test may be used to identify possible sources of Mycobaterium leprae among wild armadillos.
\end{abstract}

Key-words: Leprosy. ML Flow test. Reservoir. Armadillos.

\section{RESUMO}

Tem sido pesquisado infecção pelo Mycobaterium leprae em tatus provenientes do Estado do Espírito Santo-Brasil. O teste rápido ML Flow, foi realizado em 37 tatus selvagens, tendo sido positivo em 11 (29,7\%). O teste de ML Flow pode ser utilizado para identificar possíveis fontes de Mycobaterium leprae em tatus selvagens.

Palavras-chaves: Hanseníase. Teste ML Flow. Reservatório. Tatus.

Over the years, human beings have been considered to be the only reservoir of Mycobacterium leprae. However, leprosy in wild armadillos of the species Dasypus novemcinctus (nine-banded armadillo) was first reported in $1975^{14}$, and natural transmission among armadillos in the southern parts of the United States has been described ${ }^{13}$. Some countries in Central and South America, such as Mexico, Argentina and Brazil, have reported leprosy occurring naturally in wild armadillos ${ }^{169}$.

It seems that there is a need for increased knowledge on leprosy in wild armadillos, on order to establish whether or not armadillos are a source of M. leprae in Brazil, considering that there is some strong evidence supporting an association between human leprosy and contact with armadillos in some endemic areas, among patients in the United States $^{28}$, Mexico ${ }^{11}$ and Brazil ${ }^{10}$. The origin, range and risks of armadillo leprosy remain unclear. Other than humans, armadillos are the only other natural leprosy hosts with high rates of the disease $\mathrm{e}^{1314}$.
We have been investigating Mycobacterium leprae infection in armadillos since 1999. Our survey was conducted on armadillos captured from many rural parts of the State of Espírito Santo, Brazil. In this state, nine-banded armadillos are frequently slaughtered and eaten ${ }^{4}$. This region has high detection and prevalence rates for leprosy, and nine-banded armadillos are common and often come into contact with humans and other animals, direct and indirectly5.

Several techniques are useful for diagnosing leprosy in armadillos. The technique with highest sensitivity is PCR, followed by serology with ELISA, necropsy and histopathology'. Positive serology was found in $16 \%$ of 565 armadillos from Louisiana (United

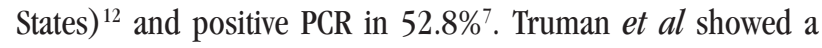
positive cross-reaction between the IgM antibodies of humans and armadillos, using ELISA, and detected the antigen PGL-I (phenolic glycolipid-I), which is specific for M. leprae ${ }^{12}$. Recently, a simple and rapid immunochromatographic flow test (the ML Flow test) became available for detecting PGL-I and IgM $^{3}$. The sensitivity of

\footnotetext{
1. Departamento de Medicina Social, Centro de Ciências da Saúde, da Universidade Federal do Espírito Santo, Vitória, ES. 2. Departamento de Dermatologia, Escola Paulista de Medicina, Universidade Federal de São Paulo, São Paulo, SP.

Financial support: The American Leprosy Missins

Address to: Dra. Patrícia D. Deps. Depto. de Medicina Social do Centro de Ciências da Saúde/UFES. Av. Marechal Campos 1468, Maruípe, 29040-090 Vitória, ES.

Tel: $552733357226 / 552799620067$

e-mail: pdeps@uol.com.br; pdeps@ccs.ufes.br

Recebido para publicação em 20/2/2006

Aceito em 12/1/2007
} 
the ML Flow test among multibacillary patients has been found to be $97.4 \%$ and the specificity to be $90.2 \%$. It does not require any special equipment and it is suitable for use in the field, particularly in tropical countries ${ }^{3}$. We did not find any reports on the use of the ML Flow test on armadillos in any language.

The test was performed on 37 animals by the addition of $5 \mu$ of the whole blood or serum samples followed by the addition of $130 \mu \mathrm{l}$ of running buffer (phosphate-buffered saline containing $0.66 \mathrm{mg}$ of BSA and 3\% Tween 20). The test result was read after 10 minutes, in accordance with the method of Bührer-Sékula $\mathrm{et} \mathrm{al}^{3}$. The ML Flow test gave positive results in 11 of these nine-banded armadillos $(29.7 \%):+2$ in 4 animals, +1 in 7 .

In human beings, the ML Flow test has been found to have a good correlation with ELISA $(91 \% ; \kappa=0.77)^{3}$, and therefore it has been used to detect nine-banded armadillos as a possible source of M. leprae. The discovery of natural transmission among armadillos in the southern part of the United States suggested the possibility that nine-banded armadillos play a role in the transmission of human leprosy in the United States ${ }^{14}$.

The ML Flow test seems to be suitable as a first test for investigating $M$. leprae in armadillos, and necropsy would only be done in positive cases. These preliminary results suggest that, in the State of Espírito Santo, nine-banded armadillos may be considered to be natural reservoir for M. leprae. The intention of the Leprosy Elimination Program is to detect all possible reservoirs of $M$. leprae, such as multibacillary patients and sources within the environment ${ }^{12}$.

\section{ACKNOWLEDGMENTS}

We are grateful to Dr Samira Bührer-Sékula for providing us with the ML Flow test; Dr Maria Aparecida Grossi for helping us with the test readings; and the American Leprosy Missions for financial support for the project.

\section{REFERENCES}

1. Amezcua ME, Escobar-Guitierrez A, Storrs EE, Dhople AM, Burchfield HP. Wild Mexican armadillo with leprosy-like infection (letter). International Journal of Leprosy and Other Mycobacteria Diseases 52:254, 1984.

2. Bruce S, Schroeder TL, Kenneth E, Howard R, Williams T, Wolf JE. Armadillo exposure and Hansen's disease: an epidemiologic survey in southern Texas. Journal of American Academy of Dermatology 43:223-228, 2000.

3. Bührer-Sékula S, Smits HL, Gussenhoven GC, Leeuwen JV, Amador RS, Fujiwara RA T, Klaster PR, Oskan L. Simple And Fast Lateral Flow Test For Classification of Leprosy Patients and Identification of Contacts With High Risk of Developing Leprosy. Journal of Clinical Microbiology 41:1991-1995, 2003.

4. Deps PD, Santos AR, Tomomori-YamashitaJ. Detection of Mycobacterium leprae DNA by PCR in blood sample from nine-banded armadillo: preliminary results (letter). International Journal of Leprosy and Other Mycobacteria Diseases 70:34-35, 2002.

5. Deps PD, Faria LV, Gonçalves VC, Silva DA, Ventura KG, Zandonade E. Epidemiological features of the leprosy transmission in relation to armadillo exposure. Hansenologia Internationalis 28:138-144, 2003.

6. Deps PD. Research of Mycobacterium leprae in nine-banded armadillos from State of Espírito Santo-Brazil. Doctoral thesis, Universidade Federal de São Paulo, SP, 2003.

7. Job CK, Drain V, Williams DL, Gillis TP, Truman RW, Sánchez RM, Deming AT, Hastings RC. Comparison of polymerase chain reaction technique with other methods for detection of Mycobacterium leprae in tissues of wild nine-banded armadillos. Leprosy Review 62:362-373, 1991.

8. Lumpikin III LR, Cox GF, Wolf JE. Leprosy in five armadillo handlers. Journal of American Academy of Dermatology 9:899-901, 1983.

9. Martinez AR, Resoagli EH, De Millan SG, Resoagli JP, Ramirez MM, Cicuta ME, De Rottio Mio, Sandoval A. Lepra salvaje en D. novemcinctus (Linneo 1758). Archivos Argentinos de Dermatologia 34:21-30, 1984.

10. Rodrigues S, Becaro E, Koizumi F, Alchorne MMA. Tatu e hanseníase. Anais Brasileiros de Dermatologia 68:340-345, 1993.

11. Thomas DA, Mines JS, Mack TM, Thomas DC, Rea TH. Armadillo exposure among Mexican-born patients with lepromatous leprosy. The Journal of Infection Diseases 156:990-993, 1987.

12. Truman RW, Kumaresan JA, McDonough, MC, Job, CK, Hastings, RC. Seasonal and spatial trends in the detectability of leprosy in wild armadillos. Epidemiology Infectious 106:549-560, 1991.

13. Walsh GP, Meyers WM, Binford CH, Gerome PJ, Wolf RH, Leininger JR. Leprosy - a zoonosis. Leprosy Review 52:77-83, 1981.

14. Walsh GP, Storrs EE, Burchfield HP, Vidrine MF, Binford CH. Leprosy-like disease occurring naturally in armadillos. Journal of Reticuloendotheliol Society 18: 374-351, 1975 